\title{
Public Universities in Brazil: Between the Social Institution and the Service Provider Organization
}

\author{
Eliane Superti * \\ Center for Applied Social Sciences, Federal University of Paraíba (UFPB). \\ Cidade Universitária, João Pessoa, Paraíba, Brasil \\ E-mail: esuperti@gmail.com \\ Brígida Ticiana Ferreira da Silva \\ Faculty of education, State University of Amapá (UEAP) \\ Campus I - Avenida FAB, Macapá, Amapá, Brasil \\ E-mail: brigidaticiane@yahoo.fr \\ Valéria Silva de Moraes Novais. \\ Faculty of education, State University of Amapá (UEAP) \\ Campus I - Avenida FAB, Macapá, Amapá, Brasil \\ E-mail: valeria.ueap@yahoo.com.br
}

The research is financed by CAPES through the notice 047/2017

\section{Abstract}

This article is a contribution to the debate about the public university in Brazil and its political confrontations. The objective was to reflect on the role of the public university as a social institution in opposition to the proposal of its transformation into a service provider organization. The importance of this discussion is to present which political project is being proposed by the Brazilian government, how it transforms the link between the university and Brazilian society and what the consequences are. Its importance also lies in pointing out what are the possibilities of resistance of public universities. The argumentation was based on qualitative analysis of documents and bibliographic research. The study is structured in four parts; introductory discussion on the historical-social construction of the public university in Brazil; reflection on its function and social responsibility; presentation of the contemporary scenario of disorganization of the public university as a social institution; and, finally, the possibilities of resistance.

Keywords: Brazilian Public University, Social Responsibility, Social institution, Service Provider Organization DOI: $10.7176 /$ RHSS/10-24-01

Publication date: December $31^{\text {st }} 2020$

\section{Introduction}

To discuss the public university in Brazil in the current scenario of suffocating budget cuts and disqualification of its efficiency, resuming the elements that mark its emergence is necessary, even if in an introductory way. Many arguments could be evoked to defend this regression, but one argument stands out as structuring to the proposed discussion, which is to explain that the public university, heir to the revolutions that delimit modernity, is a construction "in" and "of" the history of Brazilian social formation (CHAUÍ, 2003). That is, the university is not above or apart from the social relations that give shape and content to our society. The university is made in history, at the same time that as a singular social institution, it can interfere, influence, and historically rearrange the same social relations and, therefore, it cannot be thought of from a reductionist operational perspective. Its uniqueness is based on the intrinsic necessity for knowledge autonomy that it produces in the face of religion, the state, and the market. Its function is related to society in a mediated way. Historically, however, the autonomy of the Brazilian public university and the content of its social responsibility are unfinished and relative constructions.

The emergence of Brazilian public universities in the twentieth century already revealed the dialectical dynamics between social formation and university (Note 1). The first were the University of Rio de Janeiro, created in 1920, and the University of São Paulo (USP) in 1934. Both included the desire for political and economic modernization as background for their creations, in contrast to oligarchic traditionalism. The objective was to promote the cultural and scientific training of elites and professors to produce a mentality that is conducive to the cultivation of cultural and political values linked to the modernizing ideology. The group, educated liberals mainly in São Paulo, defending the campaign for the public university at the time, thought of it as the public space for the discussion and formation of values (SILVA, 2001: 299) The projection of a country integrated to modernity included the public university as one of its support pillars.

Of a strictly elitist character, the public university emerged tied to the political-cultural clash that set the tone of the multiple forces in dispute in the unfolding of the revolution of 1930. Its organization was part of a State Building process with government control and regulation. Its fragile autonomy would only become a political flag 
with the end of Varga's dictatorship and the promulgation of the 1946 constitution. Major structural and human resource struggles were on the agenda and highlighted the need for investment.

In the 1950s, with Juscelino Kubitscheck's national-developmentalism, the government stimulated business sectors linked to transnational capital and produced a strong industrial diversification. The necessity for skilled labor for this market, the growing demand for teacher training and the aspirations of the urban middle class for university education pressured the government to make investments in the expansion of the public university. But, this growth was concentrated in teaching, with the exception of USP that stimulated research. This reinforced the critical positioning of part of the Brazilian intellectuality.

The search for autonomy, better infrastructure and funding for research permeated the formation trajectory of the Brazilian public university. And, it led to the emergence of organizations in the academic environment such as the Sociedade Brasileira para o Progresso da Ciência (SBPC - Brazilian Society for the Advancement of Science) (1948) that will have an important role in the defense of the country's scientific development.

Criticism of the role played by the university until then, the desire for autonomy and freedom of organization would be the basis of an innovative proposition in the early 1960s. Headed by Darcy Ribeiro and Anísio Teixeira, a new paradigm was promoted for the public university to be implemented in Brasilia (University of Brasilia UNB), the new capital of the country, but the experiment was interrupted by the military coup of 1964.

By the force of repression, the dictatorship silenced the yearning for freedom and autonomy. But, it met the great demand for investments. Despite the violent intervention in university communities and the opening of space for the growth of private higher education, the military regime promoted the strengthening and expansion of the public university. The project of a "Great Brazil" idealized by the military could not do without or be built in the absence of the public space that formed socio-political and economic values. The projects of the dictatorial government needed the political, scientific and technical collaboration of the academic universe and obtained it to the extent that the State made funding available for research, support for the construction of new buildings, the purchase of equipment, the creation of new universities.

Another important mark of military government was the advancement of graduate studies and research. With a significant policy of granting scholarships and hiring staff, the dictatorship promoted a qualitative and quantitative leap that ensured the implementation of graduate programs. The consolidation of the Brazilian public university happened under the baton of an exclusionary and undemocratic regime.

The discussion on autonomy had no place on the program of repression, although it could not be totally eliminated. The democratization of access was not on the agenda of internal struggles and the expansion was limited to intensifying the inclusion of the middle class, which according to Chauí (2003: 70) "(...) was the consolation prize that the dictatorship offered to its base of political-ideological support, that is, to the middle class stripped of power." The university reform of 1968, combining conceptions from the academy with the interests of the regime, credited the university as a controlled space of power, but also of formation of political and professional consciousness and that intersected with social demands via the university extension. Even under the supervision of the regime, the university still produced criticism of the system and exposure of the absence of democracy and social exclusion. The university community was struggling between clearly antagonistic forces, "those who believed in its autonomy against the interests of the state and those who, knowing of its strength and importance, tried to condition it into submission" (BRITO; CUNHA, 2009: 54).

The trajectory of the public university in Brazil is intertwined and goes side by side with the politicaleconomic construction of society. The state, as an organized arena of political disputes (POULANTZAS, 1978: 124) has in the university an important force of formation of people, production of knowledge and values, which are fundamental for social development. However, the importance or centrality of the public university depends on the correlation of forces in the power struggle and varies according to political cycles. The relationship between State and university, although close, is also in constant tension. To fulfill its role, the university needs autonomy in the production of knowledge. However, insofar as autonomy is assured to the university, it produces critical reflection on the state itself. This symbiotic, tense and contradictory relationship reveals the social movement of formulation, construction and reconstruction of the model of society or the "Nation-State project" in which the university is inserted (SILVEIRA; BIANQUETE, 2016: 85).

With democratization in the 1980 s, universities were shrouded in a strong context of crisis that was not only economic, but also academic and political. The conservative transition to democracy occurred under the collapse of developmentalism and neoliberal orientation of austerity measures to control public expenses by international organizations. The public university is no longer understood as an investment for development and is now criticized as expensive and dissonant of the dynamic forces of the market that are capable of recovering the economy. In this logic, the state creates the institutional conditions for the unprecedented advancement of private higher education.

The democratic transition did not mean, therefore, the deepening of the autonomy of the university, the expansion of its potential for critical reflection, and the overcoming of its limits of social reach to expand the values of democracy and consolidate it. On the contrary, the public university is weakened. In the 1990s, with the 
government of Fernando Henrique Cardoso (FHC), the state relativized the university as a public force in favor of market forces. Stigmatized as elitist, worn down by long strikes, on the verge of budget exhaustion, the university will rethink and re-place itself in the social political scene.

This rapid history situates the discussion about the Brazilian public university. Many of the contemporary dilemmas and challenges are related to this process of formation and they show that the reflection on the public university is also the discussion on the model of society and the choices in dispute by the organization of the state. This article is a contribution to this debate with the aim of analyzing the public university as a social institution as opposed to the service provider organization The study that guided the argumentation had as methodological perspective the qualitative analysis of documents and bibliographic research. The structure of this study has three parts; reflection on the function of the public university and its social responsibility; discussion of the place reserved to the university in the scenario of the rise of neoliberal conservatism; and to conclude, the signaling of the possibilities of resistance.

\section{The role of the Public University and the Social Responsibility}

At the end of the twentieth century, discussions in academia had two central axes: university autonomy and social commitment of the university in interface with the most impoverished sectors of the population. The struggle for democratization, reduction of social inequalities and the strong privatization of higher education, put the public university facing one of its historical ghosts: its exclusionary character regarding significant sections of the population. The questions produced in the context of social movements and by the university itself about its purpose forced the university to a position on its social function.

The constitution of 1988 had postulated the character of inseparability between teaching, research and extension and it was precisely because of this last dimension of the tripod of its activities that the university reconfigures its role before society. According to Nogueira (2013: 27) "the university extension is then resumed as an instrument that will enable the university to fulfill its social function". It was about rethinking university extension as academic activity meant putting it alongside teaching and research as a means to democratize the knowledge produced and taught at the university.

The university that wanted to be autonomous sought via extension the way to overcome the criticism of its relation with the dominant and middle - better organized to claim services to the university - classes and the State itself (NOGUEIRA, 2013: 31). The public university, especially the federal ones, present in all states, sought to integrate with regional contexts, internalize and expand its relationship with society.

The path started with extension spread to teaching and research strategies. Social movements entered the university and put inclusion, interculturality, and diversity on the agenda. Companies have increased their interactions with academia in search of technological strategies and innovation to add value to products and services as a way to re-engage in the disputes of the globalized world.

The scenario of the early Twenty-First century, the intensification of democratizing social struggles led by social movements and at the same time the advance of global market forces over the State policies produced a context of strong agitation and put the government, then led by the Workers' Party (Partido dos Trabalhadores, PT) in the sensitive role of mediation. In the context of higher education, Lula's government and its successor Dilma Roussef proposed higher education policies associated with a Nation project, which in itself did not bring any news, other governments had already done the same. The innovation for the Brazilian reality was in the attempt to reconcile interests of greater social inclusion and democracy, with strong appeal to the popular sectors, with expansion and empowerment of the internal market and increased competitiveness and profitability of capital.

Serving the private initiative, the government created mechanisms such as PROUNI (Note 2) and expanded FIES (Note 3) significantly to ensure funding since it was intended to educate popular strata. These programs contributed to the concentration of on-site and online enrollments in this sector, which in 2018 corresponded to 75.4\%. According to information from the Brazilian Ministry of Education (MEC), private institutions correspond to $88.2 \%$ of Brazilian Higher Education Institutions (INEP, 2018). Such programs strengthened the privatization of higher education and resources and incentive were transferred to private institutions. According to the FIES accountability, “(...) the changes and the strong expansion of Fies, the number of formalized contracts reached the mark of 2.55 million in the period from 2010 to 2017, while in the period from 1999 to 2009 , the total amount of funded students was 564 thousand, (...)" (MEC, 2018: 30, free translation).

The government promoted significant expansion, internalization, hiring of human resources in the public university, specifically the federal ones with the REUNI (Note 4) program. The objective was to increase the number of slots, preferably in evening courses, to serve the working student, or to increase pedagogical projects for specific attendees in social vulnerability. The federal government, through the National Plan of Student Assistance (PNAES), also met the historical demand of students for specific resources for student assistance, enabling the maintenance of underprivileged students in universities (Note 5). In addition, the government decreed, by the quota law (Note 6), the most expressive presence of the popular strata in the banks of the universities and promoted new forms of admission via National High school Exam (ENEM) (Note 7) and Unified selection system 
(Sisu) (Note 8).

In addition to this effort for expansion, public-private partnerships for research, extension and innovation were stimulated and subsidized. The intention was to meet the growing demands of the market for training and production of technology focused on the competitive interests of companies. The effect was the approach between the university and the productive sector.

The result of this controversial, and target of many debates in the academy, conciliation, was to produce the expansion of public universities in all directions and with reflections until the year 2018. In 2002, the last year of the FHC government, the public undergraduate education had 700,539 enrollments (INEP, 2003) in 2018 the number had grown to 1,904,554 (INEP, 2018). The number of public universities increased from 78 in 2002 to 107 in 2018, of which $63(58 \%)$ are federal. New campuses outside the capitals and new courses, too, were deployed. Among the new courses at federal universities, many were aimed at specific audiences previously excluded from the university such as indigenous, quilombolas, and disabled peoples. The number of teachers grew significantly and the qualification also had a positive impact, increasing from $49 \%$ the number of professors with a master's degree and a doctorate in 1995 to $91.2 \%$, in 2018 considering only the federal universities (ANDIFES, 2017: 4; INEP, 2018).

The number of graduate programs recommended by Capes followed the expansion. According to the graph 1, although the public institutions offered graduate courses in greater numbers, it can be seen that between 1998 and 2002, during the last FHC government, the growth was proportionally more expressive in the private $(135 \%)$ than in the public $(23.5 \%)$. From 2002 to 2006 , the expansion slowed down $(65.5 \%)$ in the private sector and increased slightly (28.6\%) in the public sector. Between the years 2006 to 2010 the $(19.7 \%)$ increase is equivalent in the two administrative categories, but from 2010 to 2014 the public universities started to lead the growth with an increase of $41 \%$, with the private ones a growth of $27 \%$. The last quadrennial is marked by the impeachment of Dilma Rousseff in 2016 and profound political changes. In graduate school, the context was reflected in growth slowdown - with a rate of approximately $15 \%$ in both categories - and from 2018, already in Temer's government, a slight decline in public institutions.

The growth of graduate studies was very expressive in both administrative categories. In absolute numbers, the public university proved to be essential and its growth also happened in the North and Northeast regions, reducing the large regional asymmetries in the distribution of graduate studies throughout the country. Among public institutions, federal universities account for $57.6 \%$ of graduate courses.

Investments in research and the graduate courses growth have allowed the country to make an important progress in two decades, going from 23rd position to 13th among the nations that produce science the most in the world (SIDONE et al., 2016: 24). According to Andifes (2017:5), most of this knowledge - around 60\% - was produced in public universities that concentrate research laboratories and have the "widest and most efficient network of technological innovation centers, in support of verticalization and incorporation of cutting-edge technology in national production chains".

The new level that the public university has reached in the production of knowledge has placed research, innovation and technology as an important strategy for increasing productivity and socioeconomic development. The impact was significant in strategic sectors that were defined by the government as deep water oil exploration (including pre-salt), agribusiness, mainly grain production in conditions of international competitiveness, drug and vaccine production, among others. (SMAILI, 2018:13).

If the productive sector benefited from the expansion of the public university, the same happened to the popular strata. The inseparability of teaching, research and extension, the increasing qualification and the pressure for greater social inclusion made the university constitute spaces/equipment where the three elements of the tripod were present. In addition to classrooms, universities also created, renovated, expanded infrastructures - hospitals, theaters, clinics and others - that involved population care. But this was only one dimension of the process of inclusion and reduction of inequalities. The university also went inlands, contributing to the reduction of regional asymmetries, the formation of human resources outside large centers and the increase of the economy in less populous municipalities. The quota law and affirmative action policies made social groups, formerly excluded from university higher education, reach the public university.

"The University dresses as a people" said the National Coordinator of the Forum of Deans of Community and Student Affairs in the presentation of the study on the socioeconomic and cultural profile of undergraduate students between 2010 and 2014 (ANDIFES; FONAPRACE, 2014:12). Updated in 2018, the fourth edition of the study indicated that students from federal universities are predominantly women (54\%), self-declared black and brown people reach $51.02 \%$ - however, most declare themselves as brown. The students who have gross monthly family income up to 03 minimum wages reach $86.9 \%$ and, among this, those who need Student Assistance add up to $70.2 \%$. The university, originally designed to form the elite, has undergone a considerable transformation of the profile of its students (ANDIFES; FONAPRACE, 2018).

These data indicate that the university can contribute, in its own sphere, to the facing of social exclusion, although it is not capable, by itself and immediately, to solve the profound social inequalities. "A mediated 
relationship with society is inscribed in the very idea of university autonomy" (SILVA, 2001: 298) and this relationship is at the center of its social responsibility.

However, as Dias Sobrinho reveals, the meaning of this public university responsibility is not necessarily linked to social interests. The forces in dispute over different projects of society are reflected in the many interpretations about the purposes of the university. The definitions are built in the political struggle, but their greater or lesser attachment to social justice depends on the depth of their autonomy. If intended to meet market demands, universities cease to establish the mediated relationship with all society to meet specific interests. To Dias Sobrinho (2018, p 588, free translation) "as a public good, the University must contribute to economic development, but with social justice. It must produce scientific and technological knowledge, but never neglect the social Interest".

To the extent that the process of inclusion and democratization was not organized detached from the strategies of market growth dynamics, expansion of capital profitability and increase of national insertion in the world economy, the public university was also called to adapt to world tendencies and the requirements of international agencies of the globalized world. A new geopolitics of knowledge is designed with international rankings in which competitiveness, the impact of scientific-technological production and innovation are determining factors. In most of them, whatever the coverage or criteria, Brazilian public universities are listed, and "invited" to agree with the logic of academic capitalism and its conversion to a version of public law with the adoption of characteristics of private companies, whose commodities are university services, ranging from consulting to the offer of graduate lato sensu courses.

Thus, academic capitalism is effective from a set of initiatives and behaviors that are economically stimulated to increase the collection of external resources, through the subsumption of available human capital, that is, teaching work (SLAUGHTER; LESLIE, 1997). According to Somers et al. (2018), under the aegis of academic capitalism, universities begin to participate in the competitive market, subjecting their academic production and extension strategies to the demands and needs/pressures of capital.

The protagonism of the Brazilian government, between 2003 and 2016, to reinstall Brazil in the condition of a politically-economically relevant global player - through South American integration and opening of new international politics spaces - and the maintenance of the difficult combination of interests between the market and the social issue, will define important perspectives of the internationalization of the public university. And, which were reflected in the creation of the University of Latin American Integration (UNILA) and the University of international integration of Afro-Brazilian Lusophony (UNILAB).

According to Santos (2017: 41), the implementation of Unila and Unilab associate the strategic interests of Brazilian foreign policy projecting Brazil on the American and African continents. The perspective was to consolidate the Brazilian leadership in the Latin American region and as a regional power in the Southern Hemisphere (SANTOS, 2017: 38). But, the project went further, the interest was to promote an internationalization of solidarity based on the principles of educational cooperation and integration of peoples. Both universities are organized with a different political-institutional definition, with internationalization and integration as a structuring axis. To this end, they reserved places of the order of $50 \%$ for international students. These elements have epistemological developments that differentiate the pedagogical matrix and academic practice of institutions and produce a challenging innovation for public universities, the international inclusion.

The case of Unilab is undoubtedly the most emblematic of this challenge. To Santos (2017: 46), the difficulties of integrating the academic relations of black Africans in a Brazilian university are directly and perversely related to "racial-based prejudice in the imagination of Brazilian society and, indissolubly, in social practices, even if it hides behind a discourse of tolerance and racial democracy". He also indicates that African students are "(...) among the poorest and most subject populations of the planet, often deprived of minimum conditions to study in another territorial context" (SANTOS, 2017: 47, free translation). The public university created to confront this context brings in itself the hope and symbolism of the struggle for the end of social exclusion.

If the analysis of the historical constitution of the public university highlights its symbiosis with the Brazilian social formation, it is in the criticism and re-signification of its relationship with society that one can understand its role. The university's sense of social responsibility is reflected in the purposive activity that it exercises and that is based on the inseparable tripod of teaching - which function is to prepare people for the citizenship exercise and prepare qualified professionals that are political, historical, and environmentally-conscious; of research - to produce updated science, philosophy, technology, and innovation knowledges at the intersection of the demands of society; and of extension, the bridge that connects the university and society - that makes the education and knowledge produced in the university reach society, but also, for the latter to be immersed in the world of the academy, redefining its practice. The university contributes, therefore, to the process of humanization and to the development of society, this is the university's real social responsibility and this purpose constitutes it as a public good. But, the university can only fully fulfill its purpose if it has autonomy. 


\section{Public University: for what and for whom?}

Recognizing the importance of the public university and its social role does not imply denying its problems of the most diverse types. It is a matter of bringing clarity that even with problems, the university is a fundamental social institution for the construction and maintenance of a socio-economic inclusive, democratic, and critically participatory condition of the world system. But why do we see, in the Brazilian context that extends from the Temer government (2016-2018) to the Bolsonaro government (2019), this institution being constantly attacked and disqualified?

The answer is not simple. Boaventura de Sousa Santos in his speech at the a Conferência Regional de Educação Superior da América Latina e o Caribe (CRES, Regional Conference on Higher Education of Latin America and the Caribbean, 2018: 02) gave some clues to this scenario that is not only Brazilian, on the contrary, it is present in most Latin American countries. According to him, the university produces independent and critical knowledge that questions " (...) the absence of alternatives that neoliberalism tries to produce in our heads every day". The public university is the antithesis of single and apolitical thinking, it fosters reflexive and evaluative thinking that formulates and exposes political choices and their contradictions. To disqualify it, a depoliticized consensus must be formed. "That is why many of the measures against the university do not seem political, but economic, the financial or legal cuts, the fight against corruption. What is behind is the idea that the university can be a starter of alternatives and resistance" (SOUSA SANTOS, 2018: 4-5). The university is understood as adversary and as such, it must be subordinated and its nature as a social institution redefined.

The intention here is not to obscure that Brazil is going through a complex crisis of legitimacy of power, public ethics and recessive economic-financial instability, but the choices to face this context are political and reveal the variables that led to the impeachment of the president, the conformation that is intended to be attributed to the State and the place destined to the public university. The exhaustion of the conciliation of interests governments (2003-2016) and the rise of conservative right political forces resulted in the abandonment of the social perspective in favor, only, of the neoliberal-conservative ideology.

Under the focus of these interests, in which knowledge and professional training are raw materials of competitive productive processes, the university is brought to the limit of its maintenance conditions in order to transform it into an organization subjected to market rules. The intention is not to eliminate it, since it fulfills an important role for the market, the proposal is to exhaust its resistance to mischaracterize it as a social institution and make it a service-providing organization.

According to Chauí (2003: 69), an organization differs profoundly from an institution. The service provider organization is guided by an instrumental reason focused on achieving a particular goal, the university institution aspires to universality, criticizes reason and formulates the new. Focusing on a defined goal, the organization draws strategies guided by the ideas of effectiveness and success to compete with others that have the same goal. Its logic is guided by the administration of the most efficient means to achieve the purpose with planning and predictability. Reality, for the organization, is a given fact in which it exists and acts.

For the institution, reality is a construction to be questioned and investigated, its reference is in society and not in an objective. "In other words, the institution perceives itself inserted in the social and political division and seeks to define a (imaginary or desirable) universality that allows it to respond to the contradictions imposed by the division" (CHAUÍ, 2003: 36, free translation).

Market interests and neoliberal conservative policies applied to higher education support the formation of an academic capitalism or as Sousa Santos (2018: 3) defined "university capitalism" in which the parameters of efficiency and profitability exclude any pedagogical ideology that dares to think beyond the (capital and labor) market. Therefore, critically reflecting on political reality, taking a position contrary to economic consensus or questioning socially accepted positions are labeled as ideological and partisan and must be countered, if necessary, to the weight of judicial and police measures.

Social responsibility can be replaced by a sense of business opportunity. Investments are guided by market research and business plans. In this project of society, the university does not have to be a public asset, the investments it demands, including for Student Assistance, are understood as expenses that must be limited to the minimum. University higher education must be "sustainable", that is, be supported by the sale of its services to the market. The proposed strategies are to raise private funds with the sale of services, the applicability of research to commercial and productive strategies and the extension of its products to those who can pay for them. These are the guidelines contained in the FUTURE-SE (Note 9) program proposed by Bolsonaro's government for the public university. According to GOSSLER RODRIGUES DA SILVA (2020: 11) Future-se "(...) comes in tow of the needs of the capital to obey private demands that, in the short term, intend to make the federal educational institutions in locus of research development and production of knowledge committed to the logic of the commodification of education".

To justify charging for university "services", the inclusion that it was able to promote in the last two decades driven by social forces is denied and the profile of its students is ignored. They accuse the university of being elitist, taking as a reference part of the history that is not only the formation of the university, but of the Brazilian 
state itself. They deny or silence the political and economic possibilities of its maintenance as a social institution. Single thinking can only promote a single path.

Adapting the rationality of the market and its concepts assumes authoritative tones for the university administration, not being listed in the international rankings, even when fulfilling its mission and meeting the internal evaluation metrics, is an institutional demerit used as an evidence of inefficiency. In addition, analyses that diagnose all the difficulties faced as derived from management defects proliferate. The public institution is more complex than the service-providing organization. The public university is organized on the basis of the precepts of democratic management. Its leaders are elected by academic communities and by decisive collegiate, and it is not limited to administration to achieve results, because it manages research, teaching and extension as social goods and not marketable products.

The conformation of society to the neoliberal conservative ideology requires the revision of public policies. Plano Nacional de Educação (National Education Plan - PNE) 2014-2024 approved at the National Congress set targets until 2024 to narrow the gap between Brazilian educational indicators and those of the member nations of the Organization for Economic Cooperation and Development (OECD). Goal 20 proposed to raise public investment in education to 10\% of GDP, however, since 2017 PNE has been removed from the federal government's budget guidelines law. Which is aggravated by the constitutional amendment No. 95/2016, of the spending ceiling that removes from the scenario the possibility of resumption of investment and the fulfillment of goal 12 of the PNE by universities that estimated the opening of about nine hundred thousand new slots by 2024 , an expansion equivalent to $75 \%$ of the current offer. That is, the State abandoned its public policy for education.

To resize the role of the public university in the perspective of placing it as a service provider is to promote the direct, no longer mediated, relationship between the university and the market. Under this perspective, the public university loses its singular character defined by the autonomy of its knowledge. However, the university was able to contribute to solving problems in the most varied aspects of social life thanks to its uniqueness. The academic independence to generate research and the construction of knowledge that transcends specific interests and that have broadened reach by creative freedom, purposefulness and capacity for innovation are mediations that guarantee the quality of their contribution.

The autonomy of the public university in Brazil has always been relative and kept under watch. However, in the current scenario this autonomy is evidently at stake. The Final Report of the Working Group about Higher Education of the Presidency of the Chamber of Deputies, evaluated that university autonomy is one of the greatest challenges for higher education in Brazil and pointed to the recent attacks against it, including in the didacticscientific dimension. According to the report "(...) the "didactic-scientific autonomy" has often been attacked, at least since the beginning of 2019, with improper attempts at external control of teaching, research and extension activities in universities" (BRASIL; CÂMARA DOS DEPUTADOS, 2020, p 74, free translation). And, it proposes as an emergency the constitution of a special parliamentary commission to discuss regulation of Article 207 of the Federal Constitution (Note 10) to preserve university autonomy and ensure its full application.

\section{Final Considerations.}

The policy of dismantling the public university is not exclusive to the Brazilian reality, but it spreads throughout Latin America and the Caribbean. Its strength and voraciousness were the focus of the debates at CRES 2018. The final declaration of the conference highlighted "the postulate of Higher Education as a public social good, a human and universal right, and a duty of States" (CRES, 2018: 1, free translation) in strong contrast to education as a commodity.

To resist, national states are called responsibility " (...) not to subscribe to bilateral or multilateral free trade agreements that imply conceiving education as a profitable service, or encouraging forms of commodification at any level of the education system" (CRES, 2018: 2 free translation) as well as to expand public investment in universalizing slots in higher education, in supporting research, extension, and student assistance.

But the effectiveness of resistance also depends on the university itself. In agreement with Boaventura de Sousa Santos (2018: 3), the university has to rupture her limitations and radicalize her democratizing spirit. That is, the public university needs to promote an "epistemological rupture" by recognizing and embracing the plurality of other types of knowledge that is outside of it, traditional knowledge among them. The university has to "decolonize" itself, because "to defend itself as a public good, the university must make a deep self-criticism, against itself. It must leave the arrogant idea that it is the only source of knowledge, open itself to dialog with other types of knowledge" (SOUSA SANTOS, 2018: 5, free translation).

In the university's struggle to resist attempts to transform it into a service-providing organization, the extension has a fundamental and transformative role. It is no longer a question of taking the university outside the walls, but of radicalizing the democratization process by bringing non-university knowledge into the dialogue within the academy. The current context places the public university once again facing significant choices. Future research on contemporary challenges will need to discuss which paths Brazilian public universities have chosen to follow in their dialectical relationship with society. 


\section{References}

ANDIFES; FONAPRACE. (2016). IV Pesquisa do Perfil Socioeconômico e Cultural dos Estudantes de Graduação das Instituições Federais de Ensino Superior Brasileiras. Uberlândia: Universidade Federal de Uberlândia.

BRASIL; CÂMARA DOS DEPUTADOS. (2020). Relatório Final: Grupo de Trabalho destinado a acompanhar e avaliar o sistema universitário brasileiro (GT-EDSUP). Brasília: Presidência da Camâra dos Deputados.

BRITO, T.T.R; CUNHA, A. M. O. (2014).Revisitando a História da Universidade no Brasil: política de criação, autonomia e docência. Aprender - Caderno de Filosofia e Psicologia da Educação. Ano 7, núm. 12, p. 4363.

CHAUÍ, M. (2003). Sociedade, universidade e estado: autonomia, dependência e compromisso social. SESU; MEC. A universidade na encruzilhada. Seminário Universidade: por que e como reformar? Brasília: UNESCO, p. 67-76.

CRES III. (2018). Declaração. Córdoba: Universidade de Córdoba Publishing.

DIAS SOBRINHO, J. (2018). Responsabilidade social da Universidade em questão. Avaliação. Campinas; Sorocaba/SP, v. 23, n. 03, p. 586-589.

GEOCAPES. (2020). Sistema de Informações Georreferenciadas CAPES. Brasília: Capes.

GOSSLER RODRIGUES DA SILVA, F. L.; POSSAMAI, T. (2020). Programa "Future-se": impactos sobre a autonomia das instituições federais de ensino e ao direito à educação. Roteiro. Joaçaba, v. 45, n3, p. 32-48.

INEP. (2018). Sinopses Estatísticas da Educação Superior de 2016. Brasília: INEP.

INEP. (2003). Censo da Educação Superior de 2002. Brasília: INEP, 2003.

MEC. (2018) Prestação de Contas Anual e Relatório de Gestão do Exercício de 2017. Brasília: MEC.

NOGUEIRA, M. D. P. O Fórum de Pró-reitores de Extensão das Universidades Públicas Brasileiras: um ator social em construção. Interfaces - Revista de Extensão, ano 01, n. 01, p. 18-35, 2013.

POUlANTZAS, N. (1978). State, Power, Socialism. London: New Lef.

SANTOS, E. (2017) Internacionalização da educação superior - a opção geopolítica pela integração regional nos casos da UNILA e da UNILAB. Laplage em Revista, ano 03, n. 03, p. 30-51.

SIDEONE, O. J. G.; HADDAD, E. A.; MENA-CHALCO, J. P. (2016) A ciência nas regiões brasileiras: evolução da produção e das redes de colaboração científica. TransInformação, vol. 28, n. 1, p. 15-31.

SILVA, F. L. (2001). Reflexões sobre o conceito e a função da universidade pública. Revista Estudos Avançados, vol. 15, n.42, p. 295-304

SILVEIRA, Z. S.; BIANQUETE, L. (2016). Universidade moderna: dos interesses do Estado-nação às conveniências do mercado. Revista Brasileira de Educação, vol. 21, n. 64, p. 79-99.

SLAUGHTER, S,; LESLEI, L, L. (1997).Academic Capitalism: Politics, Policies and the Entrepreneurial university. Baltimore: Johns Hopkins Universy Press.

SMAILI, S. S. (2018). Universidade pública, patrimônio do povo. Folha da São Paulo, 06 julho, p 13.

SOMERS, P.; DAVIS, C.; FRY, J.; JASINSKI, L.; LEE, E. (2018). Academic capitalism and the entrepreneurial university: some perspectives from the Americas. Roteiro. Joaçaba, v.43, n.1, p. 22-42.

SOUSA SANTOS, B. (2018). Conferência inaugural da CRES 2018. Córdoba: Universidade Federal de Minas Gerais.

\section{NOTES}

Note 1. Until the proclamation of the Brazilian Republic in 1889, higher education in Brazil happened in isolated institutions. The organization of university institutions arises at the beginning of the twentieth century. The Federal University of Paraná (1912) and the University of Manaus (1913) are among the oldest, however, they were private institutions. Only from 1920 the creation universities became a government strategy giving rise to public universities.

Note 2. The Brazilian federal government's Programa Universidade para Todos (University for All Program, ProUni) offers scholarships of $50 \%$ or $100 \%$ of tuition at private colleges for underprivileged students.

Note 3. Fundo de Financiamento Estudantil (Student financing fund - FIES) was created in 1999 by the Ministry of Education (MEC) to subsidize tuition in undergraduate courses for students enrolled in private institutions of higher education.

Note 4. REUNI was a program to support the restructuring and expansion plans of Federal Universities of the federal government in 2007, with the objective of expanding the access and permanence of students in higher education.

Note 5. Plano Nacional de Assistência Estudantil (Pnaes, National Plan of Student Assistance) supports the permanence of students whose per capita family income of up to 1.5 minimum wages in the on-site undergraduate courses of federal institutions of higher education

Note 6. Law No 12.711/12, guarantees the reserve of 50\% of enrollments per course and period in federal 
universities and federal institutes to students from public education

Note 7. Exame Nacional do Ensino Médio (Enem, National High school Exam) created by MEC to test the level of learning of students who have completed high school in Brazil.

Note 8. Sistema de Seleção Unificada (Sisu, Unified selection system) is the system by which public institutions of higher education offer, nationally, slots to candidates participating in Enem.

Note 9. The FUTURE-SE program was presented in July 2019 by Ministry of Education (MEC) to the Federal Universities and institutes. With low adherence by the institutions, the project continues to be discussed within the framework of MEC

Note 10. Article 207 of the Brazilian Federal Constitution estimates that universities have didactic-scientific, administrative, financial and patrimonial management autonomy, and obey the principle of inseparability between teaching, research, and extension.

Graph 1 - Growth of Stricto Sensu Graduate Studies in Brazil 1998 - 2018

Source: Geocapes (2020)

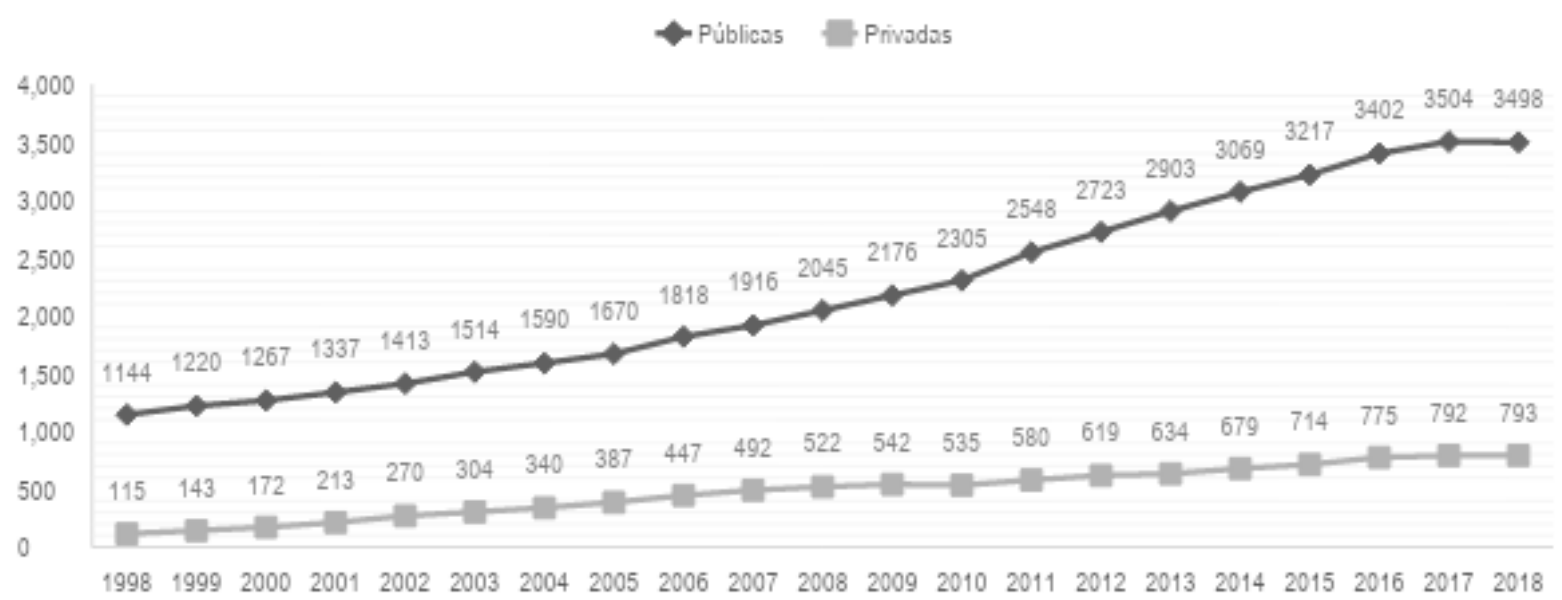

